\title{
STRUKTUR KOMUNITAS IKAN PADANG LAMUN DI PERAIRAN PANTAI WAEL TELUK KOTANIA KABUPATEN SERAM BAGIAN BARAT
}

\author{
Husain Latuconsina*, Madehusen Sangadji ${ }^{* *}$, La Sarfan $^{* * *}$ \\ *Staf Pengajar Faperik UNIDAR-Ambon, e-mail: husainlatuconsina@ymail.com \\ **Staf Pengajar Faperik UNIDAR-Ambon, e-mail: - \\ *** Alumni Faperik UNIDAR-Ambon, e-mail: -
}

\begin{abstract}
ABSTRAK
Padang lamun merupakan ekosistem laut yang memiliki produktivitas primer tinggi sehingga berperan penting bagi komunitas ikan untuk mencari makan, areal pembesaran maupun alur ruaya antar habitat terdekat. Penelitian ini dilakukan di perairan pantai Wael-Teluk Kotania, Seram Bagian Barat. Data komunitas ikan dikoleksi dengan menggunakan Jaring Insang Dasar (Bottom Gillnet) dengan ukuran mata jaring 1,5 inchi yang diletakkan sejajar garis pantai pada hamparan padang lamun. Pengamatan dilakukan sebanyak 10 kali (masing-masing 5 kali mewakili siang dan malam hari) yang dilakukan selama pasang bergerak surut. Ikan yang tertangkap berjumlah 290 individu dari 44 spesies 28 famili. Struktur komunitas ikan berfluktuasi pada siang dan malam hari. Hasil penelitian juga menemukan keragaman dan komposisi jenis sangat komunitas ikan padang lamun dipengaruhi kehadiran ikan-ikan yang berasal dari ekosistem mangrove dan terumbu karang.
\end{abstract}

Kata Kunci: Padang Lamun, Komunitas Ikan, Wael-Teluk Kotania

\section{PENDAHULUAN}

1.1. Latar Belakang

Sebagai ekosistem laut dangkal yang produktif padang lamun (seagras beds) beperan penting dalam kehidupan organisme laut (Hutomo dan Azkab, 1987). Peranan ekosistem padang lamun salah satunya bagi kehidupan komunitas ikan yaitu; sebagai daerah asuhan (nursery ground), mencari makan (feeding ground) dan perlindungan (Latuconsina et al, 2012, Latuconsinsina et al 2013, Latuconsina \& Ambo-Rappe 2013),

Peranan ekologi ekosistem padang lamun bagi komunitas ikan juga sebagai alur migrasi harian antar habitat terdekat seperti ekosistem mangrove dan terumbu karang (Unsworth, 2007; Latuconsina et al 2013; Latuconsina \& Ambo-Rappe 2013). Supriadi et al (2004), menemukan perbedaan kehadiran jenis ikan pada siang dan malam hari pada ekosistem padang lamun perairan pulau Barang Lompo-
Makassar, dimana spesies ikan yang tertangkap pada malam hari tidak didapatkan pada siang hari. Sementara itu Latuconsina \& Ambo-Rappe (2013), menemuan adanya perbedaan kelimpahan dan struktur komunitas ikan padang lamun antara siang dan malam hari, dimana kelimpahan dan dominansi selalu tinggi pada malam hari sedangkan keanekaragaman dan keseragaman komunitas ikan selalu tinggi pada siang hari pada perairan Tanjung Tiram-Teluk Ambon Dalam.

Santos et al (2002) dalam Pereira et al (2010), juga menemukan kelimpahan ikan bervariasi sepanjang hari, dimana minimum pada malam hari dan maksimum pada siang hari, dengan aktivitas migrasi kebanyakan terjadi pada pagi dan sore hari. Menurut Rooker \& Dennis (1991) dalam Pereira et al (2010), gerakan diurnal komunitas ikan berpengaruh terhadap perbedaan kelimpahan 


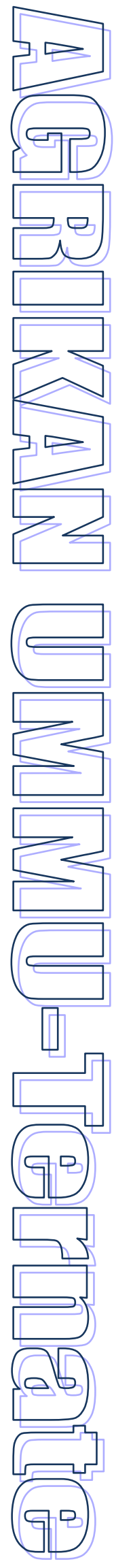

siang hari yang mungkin berkaitan dengan strategi makan.

Perairan pantai Wael Teluk Kotania memiliki ekosistem yang unik karena dijumpai ekosistem mangrove, padang lamun dan terumbu karang yang saling berdekatan. Panjang garis pantai Dusun Wael \pm kurang lebih $596 \mathrm{~m}$ dan lebar pantai $150 \mathrm{~m}$, dengan tutupan vegetasi lamun sepanjang $\pm 400 \mathrm{~m}$ dan memiliki lebar $100 \mathrm{~m}$, yang mulai detimukan tumbuh pada jarak $50 \mathrm{~m}$ dari tepi pantai, dan memiliki substrat yang bervariasi meliputi : lumpur, lumpur berpasir, pasir kasar, pasir berbatu dan patahan karang.

Dengan demikian, pengetahuan tentang distribusi temporal komunitas ikan pada eksosistem padang lamun pada Perairan Teluk Kotania khusunya pada perairan pantai Wael berdasarkan perbedaan siang dan malam hari merupakan informasi penting dalam upaya mengetahui peranan ekologi ekosistem padang lamun untuk mengetahui migrasi harian ikan padang lamun kaitannya dengan ekositem terdekat seperti mangrove dan terumbu karang, sehingga dapat dijadikan rujukan dalam pemanfaatan dan konservasi ekosistem padang lamun dan ekosistem terdekat secara lestari dan berkelanjutan.

\subsection{Tujuan Penelitian}

Penelitian ini bertujuan untuk mengetahui dan membandingkan perbedaan struktur komunitas ikan ikan padang lamun pada perairan pantai Wael berdasarkan perbedaan siang dan malam hari.

\section{METODE PENELITIAN}

\subsection{Metode Penentuan Lokasi}

Penelitian ini dilakukan pada bulan November - Desember 2012, yang berlokasi di perairan pantai Wael Kabupaten Teluk Kotania Seram Bagian Barat, pada posisi $128^{\circ} 0,3^{\prime} 36^{\prime \prime}$ BT 301'12" LS (Gambar 1).

\subsection{Parameter Lingkungan Perairan}

Parameter fisika-kimia lingkungan perairan diamati setiap kali penangkapan ikan, meliputi: kecepatan arus, suhu, salinitas, yang diukur secara insitu.

\subsection{Teknik Sampling Komunitas Ikan}

Data komunitas ikan dikoleksi dengan menggunakan Jaring Insang Dasar (Bottom Gillnet) dengan ukuran mata jaring 1,5 inchi yang diletakkan sejajar garis pantai pada hamparan padang lamun. Pengamatan dilakukan sebanyak 10 kali (5 kali mewakili siang hari dan 5 kali mewakili malam hari) yang dilakukan selama pasang bergerak surut. Ikan yang tertangkap ditempatkan pada kantong plastik yang diberi label kemudian diidentifikasi jenis (spesies), dihitung jumlah dan ditimbang beratnya. Identifikasi spesies ikan menurut Allen (1999), Kuiter dan Tonozuka $\left(2001^{a, b, c}\right)$.

\subsection{Analisa Data}

Kelimpahan relatif setiap spesies ikan padang lamun dengan perhitungan prosentase jumlah. Persamaan yang digunakan menurut Krebs (1972) dalam Setyobudiandi (2009), yaitu :

$$
\mathrm{Kr}=\frac{\mathrm{n} 1}{\mathrm{~N}} \boldsymbol{x} 100 \%
$$

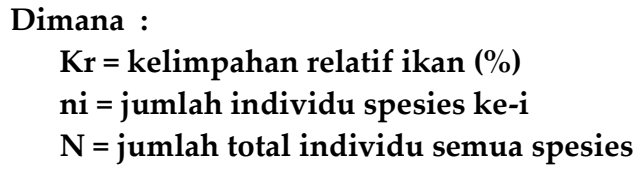

Ferekuensi kehadiran menujukkan luasnya penyebaran temporal ikan padang lamun antara siang dan malam hari yang terlihat dari nilai frekuensi ikan yang tertangkap selama periode pengamatan. Persamaan menurut Misra (1968) dalam Setyobudiandi et al (2009) yaitu :

$$
\begin{aligned}
\mathrm{Fi}= & \frac{\mathrm{t}}{\mathrm{T}} \times 100 \% \\
\mathrm{Fi}= & \text { Frekuensi kehadiran ikan spesies ke-i } \\
& \quad \text { yang tertangkap }(\%) \\
\mathrm{Ti}= & \begin{array}{l}
\text { Jumlah pengamatan dimana spesies } \\
\text { ke-i tertangkap }
\end{array} \\
\mathrm{T}= & \text { Jumlah seluruh pengmatan }
\end{aligned}
$$$$
\text { Dimana : }
$$

Struktur komunitas ikan yang dianalisa meliputi Indeks Dominansi, Indeks Keanekaragaman dan Indeks Keseragaman.

Nilai indeks Dominansi memberikan gambaran tentang dominansi ikan dalam suatu komunitas ekologi, yang dapat menerangkan 

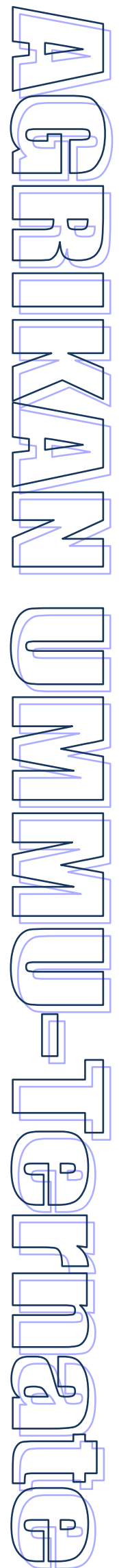

bilamana suatu spesies ikan lebih banyak terdapat selama pengambilan data, dengan formula Margalef (1958) dalam odum (1983):

$$
C=\Sigma\left(\frac{n 1}{N}\right)^{2}
$$

$$
\begin{aligned}
& \text { Dimana : } \\
& \begin{array}{l}
\mathrm{C}=\text { Indeks Dominansi Simpson, } \\
\mathrm{N}=\text { Jumlah individu seluruh spesies, } \\
\mathrm{ni}=\text { Jumlah individu dari spesies ke-i. }
\end{array}
\end{aligned}
$$

Indeks keanekaragaman adalah nilai yang dapat menunjukkan keseimbangan keanekaragaman dalam suatu pembagian jumlah individu tiap spesies. Sedikit atau banyaknya keanekaragaman spesies ikan dapat dilihat dengan menggunakan indeks keanekaragaman. Indeks keanekaragaman mempunyai nilai terbesar jika semua individu berasal dari spesies yang berbeda-beda. Sedangkan nilai terkecil didapat jika semua individu berasal dari satu satu spesies saja (Odum, 1983).
Nilai indeks keanekaragaman Shannon $\left(H^{\prime}\right)$ menurut Shannon and Wiener (1949) dalam Odum (1983) dihitung menggunakan formula :

$$
\mathbf{H}^{\prime}=-\sum \mathbf{P i} \ln (\mathbf{P i})
$$

Dimana :

$$
\begin{aligned}
& \mathrm{H}^{\prime}=\text { Indeks Keanekaragaman, } \\
& \mathrm{Pi}=\text { Proporsi jumlah individu (ni/N). }
\end{aligned}
$$

Nilai Indeks keseragaman (E), semakin besar menunjukkan kelimpahan yang hampir seragam dan merata antar spesies (Odum, 1983). Formula dari indeks keseragaman Pielou (E) menurut Pielou (1966) dalam Odum (1983) yaitu:

$$
\mathrm{E}=\frac{\mathrm{H}^{8}}{\log 5}
$$

Dimana :

$$
\begin{aligned}
& \mathrm{E}=\text { Indeks Keseragaman, } \\
& \mathbf{H}^{\prime}=\text { Indeeks Keanekaragaman, } \\
& \mathrm{S}=\text { Jumlah spesies. }
\end{aligned}
$$

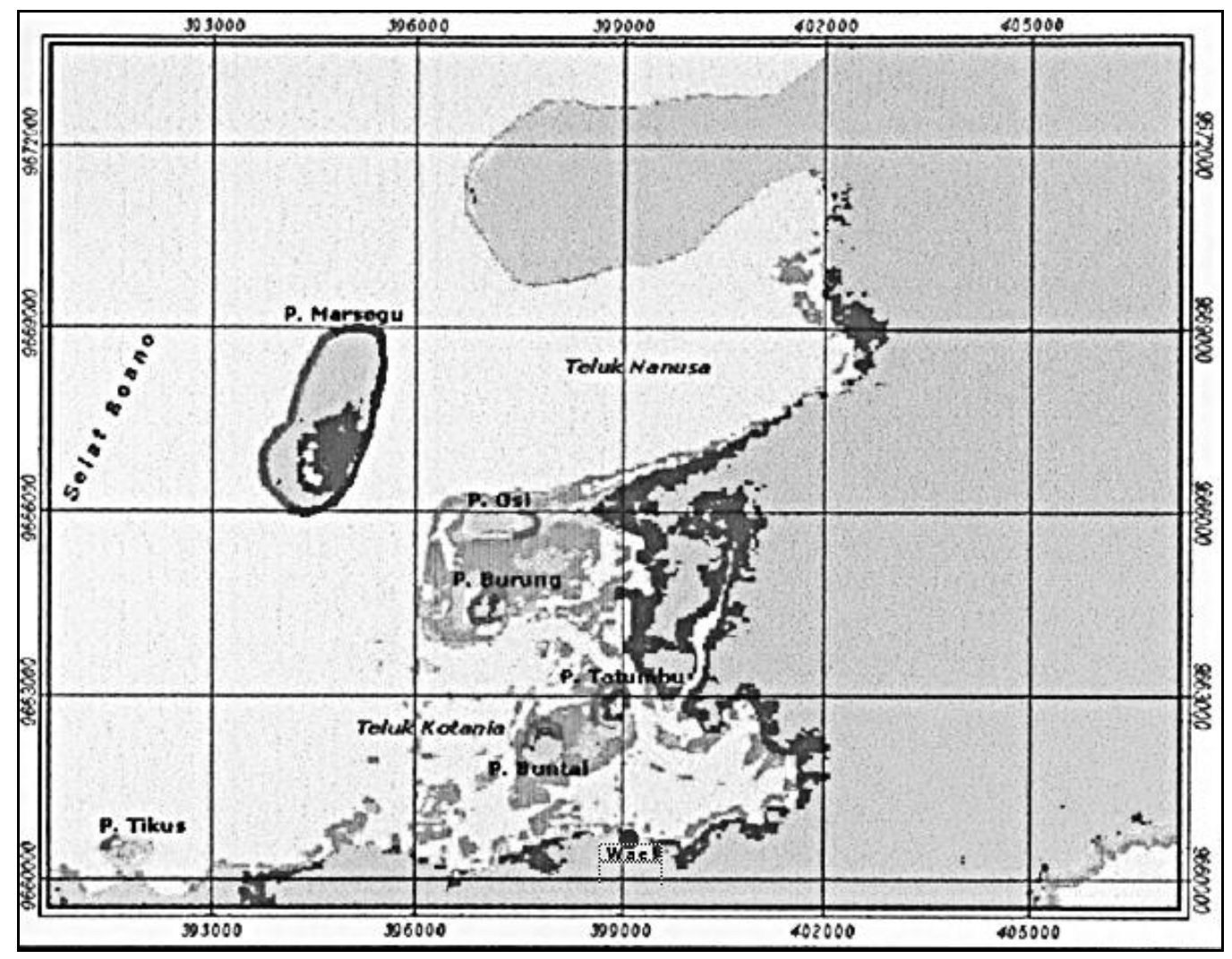

Gambar 1. Lokasi Penelitian pada ekosistem padang lamun Perairan Pantai WaelTeluk Kotania, Kabupaten Seram Bagian Barat. 


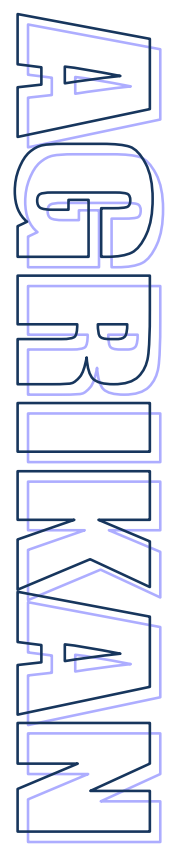

Tabel 1. Kriteria Nilai Struktur Komunitas (Setyobudiandy et al, 2009).

\begin{tabular}{ccc}
\hline Indeks & Kisaran & Kategori \\
\hline \multirow{2}{*}{ Dominansi (C) } & $0,00<\mathrm{C} \leq 0,50$ & Rendah \\
& $0,50<\mathrm{C} \leq 0,75$ & Sedang \\
& $0,75<\mathrm{C} \leq 1,00$ & Tinggi \\
\hline \multirow{3}{*}{ Keanekaragaman $\left(\mathrm{H}^{\prime}\right)$} & $\mathrm{H}^{\prime} \leq 2$ & Rendah \\
& $2,0<\mathrm{H}^{\prime} \leq 3$ & Sedang \\
& $\mathrm{H}^{\prime} \geq 3,0$ & Tinggi \\
\hline \multirow{2}{*}{ Keseragaman $(\mathrm{E})$} & $0,00<\mathrm{E} \leq 0,50$ & Komunitas dalam kondisi Tertekan \\
& $0,50<\mathrm{E} \leq 0,75$ & Komunitas dalam kondisi Labil \\
& $0,75<\mathrm{E} \leq 1,00$ & Komunitas dalam kondisi Stabil \\
\hline
\end{tabular}

\section{HASIL DAN PEMBAHASAN}

3.1. Gambaran Umum Perairan Pantai Wael

Secara geografis perairan pantai Wael berada pada perairan Teluk Kotania, Kabupaten Seram Bagian Barat. Sebelah Utara berbatasan dengan pulau Buntal, Sebelah Barat Berbatasan dengan Perairan Airpesy dan sebelah Timur berbatasan dengan perairan Kotania. Perairan pantai Wael memiliki potensi ekosistem pesisir berupa ekosistem mangrove, ekosistem padang lamun dan terumbu karang yang saling berdekatan dan mempengaruhi kelimpahan dan keragaman sumberdaya hayati ikan.

\subsection{Parameter Lingkungan Perairan}

Parameter lingkungan pada selama penelitian cukup berfluktuasi antara periode siang dan malam hari seperti yang terlihat pada Tabel 2.
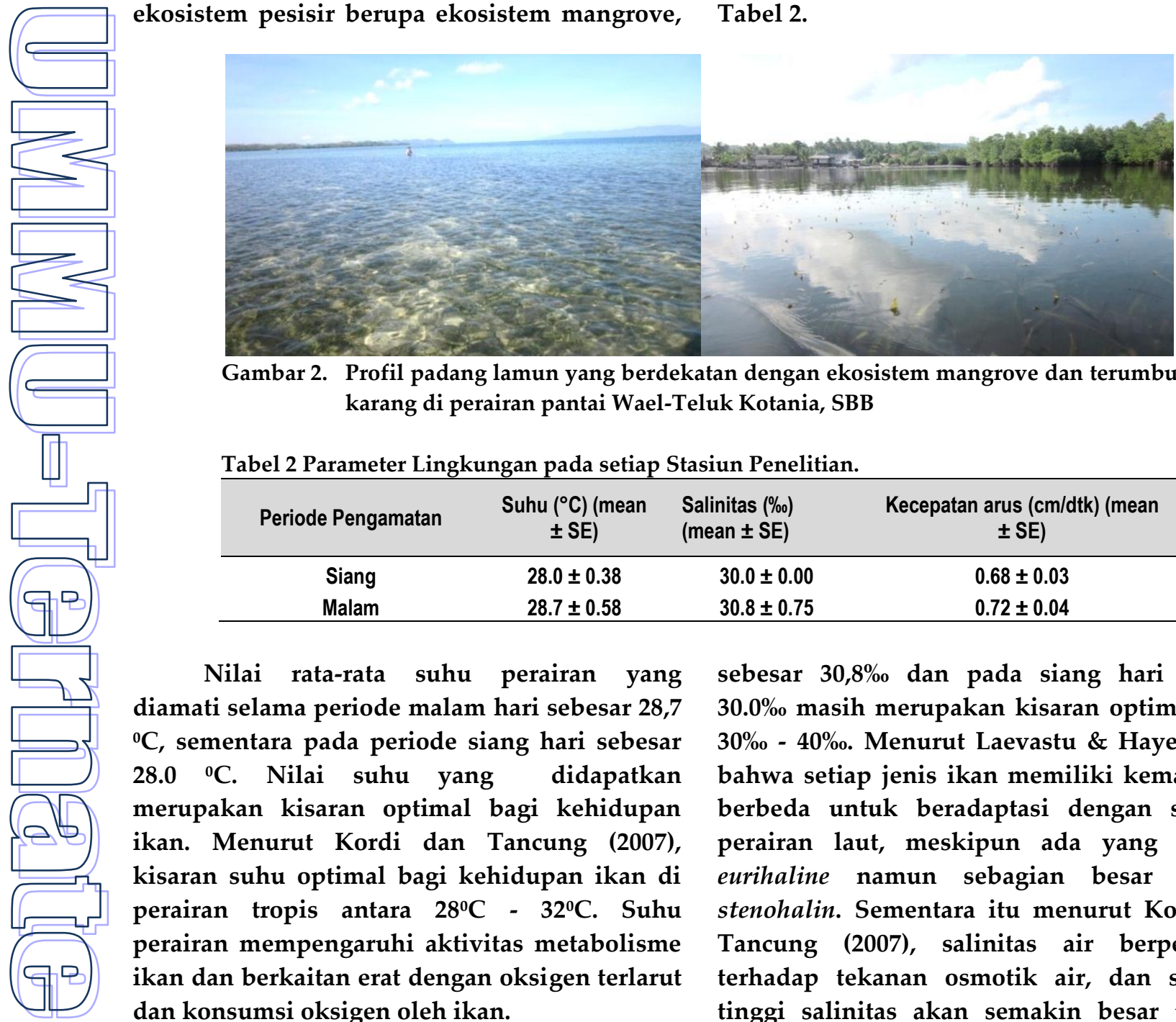

Gambar 2. Profil padang lamun yang berdekatan dengan ekosistem mangrove dan terumbu karang di perairan pantai Wael-Teluk Kotania, SBB

Tabel 2 Parameter Lingkungan pada setiap Stasiun Penelitian.

\begin{tabular}{cccc} 
Periode Pengamatan & $\begin{array}{c}\text { Suhu }\left({ }^{\circ} \mathrm{C}\right)(\text { mean } \\
\pm \mathrm{SE})\end{array}$ & $\begin{array}{c}\text { Salinitas }(\% \circ) \\
(\text { mean } \pm \text { SE) }\end{array}$ & $\begin{array}{c}\text { Kecepatan arus (cm/dtk) (mean } \\
\pm \text { SE) }\end{array}$ \\
\hline Siang & $28.0 \pm 0.38$ & $30.0 \pm 0.00$ & $0.68 \pm 0.03$ \\
Malam & $28.7 \pm 0.58$ & $30.8 \pm 0.75$ & $0.72 \pm 0.04$ \\
\hline
\end{tabular}

Nilai rata-rata suhu perairan yang diamati selama periode malam hari sebesar 28,7 ${ }^{\circ} \mathrm{C}$, sementara pada periode siang hari sebesar $28.0{ }^{\circ} \mathrm{C}$. Nilai suhu yang didapatkan merupakan kisaran optimal bagi kehidupan ikan. Menurut Kordi dan Tancung (2007), kisaran suhu optimal bagi kehidupan ikan di perairan tropis antara $28^{\circ} \mathrm{C}-32^{\circ} \mathrm{C}$. Suhu perairan mempengaruhi aktivitas metabolisme ikan dan berkaitan erat dengan oksigen terlarut dan konsumsi oksigen oleh ikan.

Untuk nilai rata-rata salinitas yang diamati selama periode siang dan malam hari sebesar $30,8 \%$ dan pada siang hari sebesar 30.0\% masih merupakan kisaran optimal yaitu 30\% - 40\%. Menurut Laevastu \& Hayes (1982) bahwa setiap jenis ikan memiliki kemampuan berbeda untuk beradaptasi dengan salinitas perairan laut, meskipun ada yang bersifat eurihaline namun sebagian besar bersifat stenohalin. Sementara itu menurut Kordi dan Tancung (2007), salinitas air berpengaruh terhadap tekanan osmotik air, dan semakin tinggi salinitas akan semakin besar tekanan osmotiknya yang berpengaruh terhadap biota perairan. 
Kecepatan arus selama pengamatan pada periode siang dan malam memiliki nilai ratarata $0,72 \mathrm{~cm} / \mathrm{dtk}$ dan rata-rata pada periode siang hari sebesar $0,68 \mathrm{~cm} / \mathrm{dtk}$. Menurut Welch (1980) dalam Wulandari (2004) arus dengan kecepatan kurang dari $10 \mathrm{~cm} / \mathrm{dtk}$ tergolong perairan dengan arus yang sangat lemah, artinya nilai kecepatan arus yang didapatkan selama penilitian pada periode siang dan malam hari tergolong sangat lemah. Menurut Laevastu dan Hayes (1981), arus berpengaruh bagi ikan terhadap transportasi telur, larva, dan ikan-ikan kecil, dan juga berperan dalam menentukan orientasi migrasi.

\subsection{Kelimpahan Komunitas Ikan padang Lamun \\ Kelimpahan relative dan frekuensi} kehadiran spesies ikan pada ekosistem padang lamun di perairan pantai Wael-Tekuk Kotanian selama periode pengamatan ukup berfluktuasi seperti yang terlihat pada Tabel 3 yang memperlihatkan bahwa spesies Siganus canaliculatus lebih melimpah pada malam hari (nokturnal) dan selau ditemukan setiap kali pengamatan dengan frekuensi kehadiran $100 \%$, sementara pada siang hari $60 \%$ frekuensi kehadirannya. Hal yang sama ditemukan Latuconsina dan Ambo-Rappe (2013) pada perairan Tanjung Tiram-Teluk Ambon dimana Siganus canaliculatus ditemukan pada siang dan malam hari namun dengan kelimpahan tertinggi pada periode malam hari sehingga diduga bersifat nocturnal yang lebih aktif pada malam hari.

Tingginya kelimpahan Siganus canaliculatus baik pada periode siang maupun malam hari menunjukkan bahwa spesies tersebut memiliki asosiasi yang kuat dengan ekosistem padang lamun, baik sebagai tempat mencari makan maupun areal pembesaran seperti yang ditemukan oleh Latuconsina et al (2013) di perairan Teluk Ambon Dalam.

Sementara itu lebih melimpahnya ikan pada malam hari diduga terkait sifat nokturnal ikan yang lebih aktif pada malam hari seperti yang ditemukan Supriadi et al. 2004 pada perairan pulau Barrang Lompo. Fenomena ini diduga terkait dengan sifat ikan yang lebih aktif pada siang hari (diurnal), maupun yang aktif pada malam hari (nokturnal). Sementara sebagian besar ikan dominan yang ditemukan pada periode siang dan malam hari karena mampu beradaptasi dengan baik pada cahaya terang dan gelap. Menurut Fujaya (2004) dalam retina mata ikan-ikan teleostei umumnya memiliki sel kon yang dipakai untuk aktifitas siang hari atau cahaya terang (penglihatan fotopik) dan sel rod yang bertanggung jawab pada penglihatan cahaya samar (Penglihatan scotopik).

\subsection{Jumlah Individu, Spesies dan Famili}

Jumlah individu ikan yang ditemukan selama penelitian sebanyak 290 individu meliputi 44 speseis dari 28 famili. Total individu ikan yang ditemukan pada siang hari sebanyak 121 individu, meliputi 25 spesies dari 18 famili, sedangkan total jumlah individu ikan yang ditemukan pada malam hari sebanyak 169 individu, meliputi 29 spesies dari 22 famili. Jumlah individu dan keragaman spesies ikan padang lamun di perairan pantai Wael-Teluk Kotania antara siang dan malam hari menunjukkan adanya fluktuasi (Gambar 5).

Berdasarkan Gambar 5, terlihat bahwa kelimpahan induvidu ikan lebih tinggi pada malam hari dengan kisaran kelimpahan 13-44 individu dengan nilai rata-rata 38,8 individu sebaliknya cenderung menurun pada siang hari dengan kisaran kelimpahan 9-37 dengan nilai rata-rata kelimpahan 24 induvidu.

Keragaman spesies dan famili juga cenderung lebih tinggi pada malam hari di bandingkan siang hari dengan kisaran jumlah spesies 5-15 dan jumlah famili 4-12 dengan ratarata jumlah spesies 7 dan famili 6 sedangkan pada siang hari dengan kisaran jumlah spesies 4-11 dan kisaran jumlah famili 4-9 dengan nilai rata-rata jumlah spesies $\mathbf{1 0}$ dan famili 9.

Tingginya keragaman jenis ikan padang lamun perairan Wael-Teluk Kotania selain dipengaruhi oleh parameter fisika kimia perairan dan habitat lamun, juga dipengaruhi oleh habitat mangrove dan terumbu karang. Seperti yang ditemukan Latuconsina \& Ambo Rappe (2013: Ambo-Rappe et al, 2013).

Ekosistem mangrove maupun terumbu karang dikenal memiliki keragaman spesies ikan yang tinggi, sehingga ekosistem padang lamun yang terletak diantara ekosistem mangrove dan terumbu karang ikut memiliki 


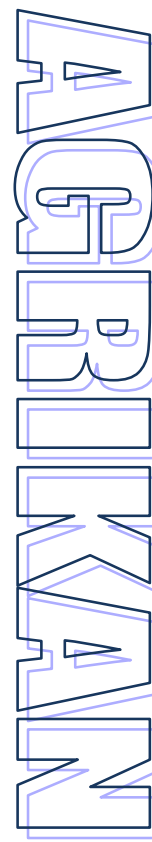

keragaman spesies. Selain itu, tingginya tingkat keragaman spesies ikan pada ekosistem padang lamun juga terkait dengan fungsi ekologi ekosistem padang lamun sebagai sumber makanan dan tempat perlindungan bagi sebagian besar biota laut.

Menurut Hemingga dan Duarte (2000), terdapat empat faktor yang relevan terkait dengan variabilitas komunitas ikan padang lamun, yaitu : (1) struktur vegetasi lamun, (2) tingkat larva dan ikan juvenil yang menghuni Seram Barat. padang lamun, mortalitas dan proses migrasi, (3) lokasi vegetasi lamun terhadap habitat lainnya, dan (4) parameter fisika kimia pada habitat lamun.

Sebagaimana menurut Bell dan Pollard (1989), bahwa hubungan yang kuat terjadi antara padang lamun dan habitat yang terdekat, dimana kelimpahan relatif dan komposisi spesies ikan di padang lamun menjadi tergantung pada tipe (terumbu karang, estuaria, mangrove) dan jarak dari habitat yang terdekat.

Tabel 3. Kehadiran dan Kelimpahan relatif ikan padang lamun perairan pantai Wael-Teluk Kotania,

\begin{tabular}{|c|c|c|c|c|c|c|c|}
\hline \multirow[b]{2}{*}{ Famili } & \multirow[b]{2}{*}{ Spesies } & \multicolumn{3}{|c|}{ Periode Siang } & \multicolumn{3}{|c|}{ Periode Malam } \\
\hline & & $\Sigma$ & $\mathrm{Kr}(\%)$ & $\begin{array}{l}\text { Fk } \\
(\%)\end{array}$ & $\Sigma$ & $\mathrm{Kr}(\%)$ & $\begin{array}{l}\text { Fk } \\
(\%)\end{array}$ \\
\hline \multirow[t]{2}{*}{ I. SCARIDAE } & Scarus gobban (Forsskal,1775) & 2 & 1.65 & 40 & 6 & 3.55 & 80 \\
\hline & Chlorurus bleekeri (de Beaufort,1940) & 1 & 0.83 & 20 & 0 & 0.00 & 0 \\
\hline II.PLOTOSIDAE & Plotosus anguilaris (Bloch,1794) & 0 & 0.00 & 0 & 9 & 5.33 & 40 \\
\hline \multirow[t]{2}{*}{ III. SIGANIDAE } & Siganus canaliculatus (Park,1797) & 19 & 15.70 & 60 & 71 & 42.01 & 100 \\
\hline & Siganus doliatus (Cuvier,1830) & 1 & 0.83 & 20 & 0 & 0.00 & 0 \\
\hline \multirow[t]{3}{*}{ IV. LUTJANIDAE } & Lutjanus carponotatus (Richardson,1842) & 13 & 10.74 & 80 & 5 & 2.96 & 80 \\
\hline & Lutjanus fulviflamma (Forsskal,1775) & 0 & 0.00 & 0 & 2 & 1.18 & 20 \\
\hline & Lutjanus Iutjanus Bloch, 1790 & 1 & 0.83 & 20 & 0 & 0.00 & 0 \\
\hline \multirow{5}{*}{ V. LETHRINIDAE } & Lethrinus harak (Forsskal,1775) & 18 & 14.88 & 80 & 16 & 9.47 & 80 \\
\hline & Lethrinus lentjan (Lacepede,1802) & 2 & 1.65 & 20 & 5 & 2.96 & 80 \\
\hline & Lethrinus ornatus (Valenciennes, 1830) & 28 & 23.14 & 40 & 2 & 1.18 & 20 \\
\hline & Lethrinus erythropterus Valenciennes, 1830 & 0 & 0.00 & 0 & 1 & 0.59 & 20 \\
\hline & Lethrinus variegatus Valenciennes, & 1 & 0.83 & 20 & 0 & 0.00 & 0 \\
\hline VI. GERREIDAE & Gerres oyena (Forsskal,1755) & 1 & 0.83 & 20 & 9 & 5.33 & 40 \\
\hline VII. PLATYCEPHALIDAE & Papilloculiceps nematophthalmus (Gunther,1860) & 2 & 1.65 & 20 & 3 & 1.78 & 40 \\
\hline \multirow[t]{4}{*}{ VIII. SERRANIDAE } & Epinephelus ongus (Bloch,1790) & 1 & 0.83 & 20 & 2 & 1.18 & 20 \\
\hline & Centrogenys vaigiensis (Quoy \& Gaimard, 1824) & 0 & 0.00 & 0 & 1 & 0.59 & 20 \\
\hline & Cromileptes altivelis (Valenciennes, 1828) & 0 & 0.00 & 0 & 2 & 1.18 & 20 \\
\hline & Plectropomus maculatus (Bloch,1790) & 0 & 0.00 & 0 & 1 & 0.59 & 20 \\
\hline IX. BELONIDAE & Tylosurus crocodilus (Peron \& Lesueur,1821) & 0 & 0.00 & 0 & 1 & 0.59 & 20 \\
\hline \multirow[t]{2}{*}{ X. DIODONTIDAE } & Diodon litorosus Shaw,1804 & 0 & 0.00 & 0 & 1 & 0.59 & 20 \\
\hline & Diodon holacanthus (Linnaeus,1758) & 1 & 0.83 & 20 & 0 & 0.00 & 0 \\
\hline XI. SCORPAENIDAE & Synanceja horrida (Linnaeus,1766) & 0 & 0.00 & 0 & 1 & 0.59 & 20 \\
\hline XII. NEMIPTERIDAE & Scolopsis ciliatus (Lacepede,1802) & 1 & 0.83 & 20 & 0 & 0.00 & 0 \\
\hline XIII. POMACENTRIDAE & Hemiglyphidodon plagiometopon (Bleeker,1852) & 2 & 1.65 & 40 & 0 & 0.00 & 0 \\
\hline XIV. KYPHOSIDAE & Kyphosus bigibbus Lacepede, 1802 & 0 & 0.00 & 0 & 4 & 2.37 & 20 \\
\hline XV. MUGILIDAE & Mugil cephalus Linneaus, 1758 & 0 & 0.00 & 0 & 2 & 1.18 & 40 \\
\hline XVI. HEMIRAMPHIDAE & Hemiramphus far (Forsskal,1755) & 0 & 0.00 & 0 & 1 & 0.59 & 20 \\
\hline XVII. SPYRAENIDAE & Sphyraena jello (Cuvier,1829) & 0 & 0.00 & 0 & 1 & 0.59 & 20 \\
\hline \multirow[t]{2}{*}{ XVIII. HOLOCENTRIDAE } & Myripristis adusta (Bleeker,1853) & 0 & 0.00 & 0 & 1 & 0.59 & 20 \\
\hline & Sargocentron rubrum (Forsskal,1775) & 0 & 0.00 & 0 & 1 & 0.59 & 20 \\
\hline XIX. SYNGNATHIDAE & Syngnathoides biaculeatus (Bloch, 1785) & 1 & 0.83 & 20 & 0 & 0.00 & 0 \\
\hline XX. ECENEIDAE & nora (Linnaeus, 1758) & 1 & 0.83 & 20 & 0 & 0.00 & 0 \\
\hline \multirow{2}{*}{ XXI. CARANGIDAE } & Caranx sexfasciatus (Quoy \& Gaimard,1825) & 12 & 9.92 & 60 & 11 & 6.51 & 20 \\
\hline & Selar boops (Cuvier,1833) & 2 & 1.65 & 20 & 0 & 0.00 & 0 \\
\hline XXII. TERAPONTIDAE & Pelates quadrilineatus (Bloch,1790) & 4 & 3.31 & 20 & 6 & 3.55 & 40 \\
\hline XXIII. ACANTHURIDAE & Acanthurus xanthoptherus Valenciennes, 1835 & 0 & 0.00 & 0 & 1 & 0.59 & 20 \\
\hline \multirow[t]{2}{*}{ XXIV. MULLIDAE } & Parupeneus indicus (Shaw,1903) & 0 & 0.00 & 0 & 1 & 0.59 & 20 \\
\hline & Parupeneus barberinus (Lacepede,1801) & 1 & 0.83 & 20 & 0 & 0.00 & 0 \\
\hline \multirow[t]{2}{*}{ XXV. CHAETODONTIDAE } & Chelmon rostratus (Linnaeus, 1758) & 0 & 0.00 & 0 & 1 & 0.59 & 20 \\
\hline & Parachaetodon ocellatus (Cuvier,1831) & 1 & 0.83 & 20 & 0 & 0.00 & 0 \\
\hline XXVI. LEIOGNATHIDAE & Leiognathus smithursti (Ramsay \& Ogilby,1886) & 0 & 0.00 & 0 & 1 & 0.59 & 20 \\
\hline XXVII. BALISTIDAE & Balistoides viridescens (Bloch \& Schneider,1801) & 1 & 0.83 & 20 & 0 & 0.00 & 0 \\
\hline XXVIII. LABRIDAE & Choerodon anchorago (Bloch,1791) & 4 & 3.31 & 20 & 0 & 0.00 & 0 \\
\hline$\Sigma=28$ & $\Sigma=44$ & 121 & 100.0 & & 169 & 100 & \\
\hline
\end{tabular}



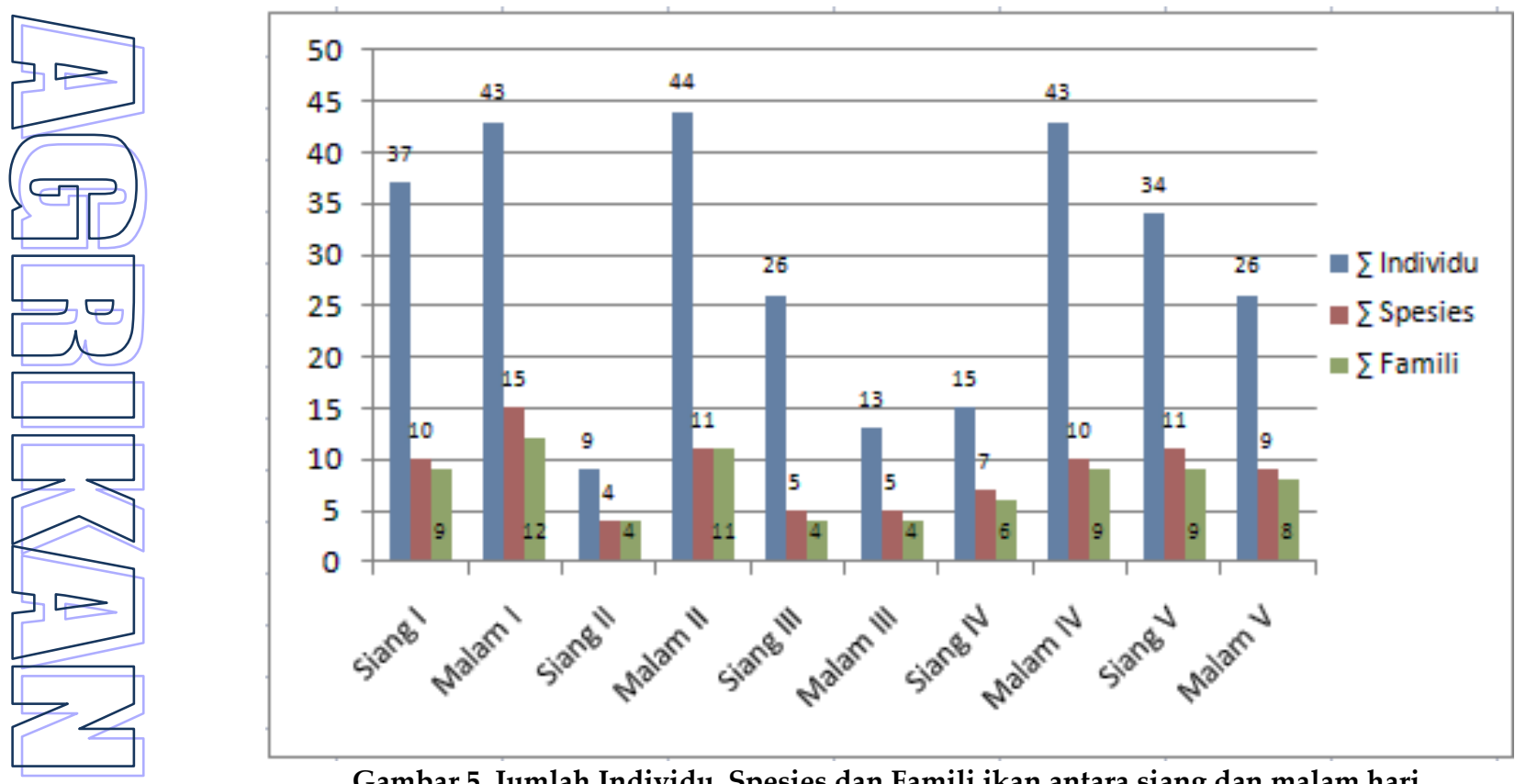

Gambar 5. Jumlah Individu, Spesies dan Famili ikan antara siang dan malam hari.

Ambo-Rappe et al 2013 mnemuan adanya kerapatan vegetasi lamun yang berbeda dan kedekatannya dengan ekosistem mangrove dan terumbu karang akan turut memengaruhi struktur komunitas ikan secara spasial. Fenomena ini diperkuat dengan ditemukannya beberapa jenis ikan yang berasosiasi kuat dengan ekosistem mangrove selama fase juvenile seperti dari famili Carangidae (Niarita et al, 1996), dan ikan-ikan khas terumbu karang seperti dari famili Serranidae, Lutjanidae, lethirinidae, dan Labridae (Allen, 1999).

Kelimpahan ikan yang lebih tinggi pada malam hari membuktikan adanya distribusi harian ikan antara ekosistem padang lamun dan habitat terdekat seperti mangrove dan terumbu karang (Nagelkerken et al. 2000 dan Pereira et al. (2010). Banyak spesies ikan menggunakan lingkungan terumbu karang sebagai termpat berlindung selama siang hari, namun memiliki hubungan erat dan bergantung pada ekosistem padang lamun dan habitat lainnya untuk mecari makan pada malam dan sore hari (Pereira et al. 2010).

\subsection{Struktur Komunitas Ikan}

Komunitas merupakan agregasi dari interaksi spesies dalam suatu habitat, dimana interaksi antar jenis lebih kompleks dan bervariasi pada suatu komunitas dengan tingkat keanekaragaman tinggi sehingga terjadi perpindahan energi (food web), predasi dan kompetisi (Brower et al 1990). Hasil analisa struktur komunitas ikan yang meliputi Dominansi, keanekaragaman dan keseragaman jenis seperti terlihat pada Tabel 5 .

Tabel 5. Struktur Komunitas Ikan secara Temopral antara siang dan malam hari

\begin{tabular}{lcccccccccccc}
\multirow{2}{*}{ Struktur Komunitas Ikan } & \multicolumn{1}{c}{ Periode Siang Hari } & \multicolumn{1}{c}{ Periode Malam Hari } & \multirow{2}{*}{ Kategori } \\
\cline { 2 - 11 } & I & II & III & IV & V & I & II & III & IV & V & \\
Dominansi (C) & 0.21 & 0.33 & 0.43 & 0.17 & 0.23 & 0.19 & 0.20 & 0.30 & 0.33 & 0.30 & Rendah \\
Keanekaragaman (H') & 1.86 & 1.21 & 1.06 & 1.84 & 1.81 & 2.20 & 1.95 & 1.38 & 1.5 & 1.61 & Sedang \\
Keseragaman (E) & 0.81 & 0.88 & 0.66 & 0.95 & 0.75 & 0.81 & 0.81 & 0.86 & 0.65 & 0.73 & Labil \\
\hline
\end{tabular}

Berdasarkan Tabel 4, memperlihatkan adanya fluktuasi struktur komunitas ikan antara periode siang dan malam hari, dimana indeks dominansi cenderung lebih tinggi pada siang hari sementara itu indeks keanekaragaman dan keseragaman lebih tinggi pada siang hari. Meskipun demikian selama pengamatan struktur komunitas antara siang dan malam masih masuk dalam kategori yang sama, yaitu indeks dominansi masuk kategori 


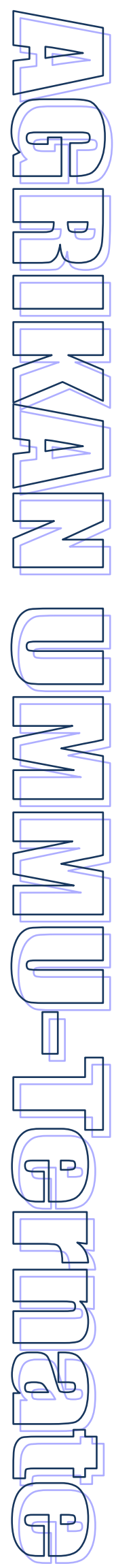

rendah, indeks keanekaragaman masuk kategori sedang, sementara indeks keseragaman masuk kategori stabil.

Menurut Brower et al (1990), keanekaragaman jenis adala suatu ekspresi dari struktur komunitas, dimana suatu komunitas dikatakan memiliki keanekaragaman jenis tinggi, jika proporsi antar jenis secara keseluruhan sama banyak, sehingga jika ada beberapa jenis dalam komunitas memiliki kelimpahan (dominansi yang besar) maka keanekaragaman dan keseragamannya rendah.

Menurut Soeginato (1995), struktur suatu komunitas tidak hanya dipengaruhi oleh hubungan antar sepsies, tetapi juga oleh jumlah relatif organisme dari spesies-sepsies tersebut, sehingga kelimpahan relatif suatu spesies dapat mempengaruhi fungsi suatu komunitas, distribusi individu dalam komunitas, bahkan dapat mempengaruhi keseimbangan komunitas dan akhirnya pada stabilitas komunitas tersebut.

\section{PENUTUP}

\subsection{Kesimpulan}

1. Kelimpahan, jumlah spesies dan famili ikan lebih tinggi pada periode malam

hari dibandingkan siang hari menunjukkan adanya sifat nokturnal dan dan diurnal ikan.

2. Struktur komunitas ikan berfluktuasi pada malam siang dan malam hari, dimana indeks keanekaragaman dan keseragaman tertinggi pada siang hari dan sebaliknya indeks dominansi tertinggi pada malam hari.

3. Tingginya kelimpahan dan keragaman spesies ikan padang lamun cukup dipengaruhi oleh keberadaan ekosistem mangrove dan terumbu karang, dengan ditemukannya spesies-spesies khas penghuni ekosistem mangrove dan terumbu karang.

\subsection{Saran}

Diperlukan penelitian lanjutan terkait dengan orientasi keberadaan ikan pada siang dan malam hari, apakah untuk mencari makan, memijah maupun aktivitas biologis lainnya untuk kepentingan pemanfaatan dan pengelolaan ekosistem padang lamun beserta ekosistem terdekat sehingga dapat dimanfaatkan secara berkelanjutan.

\section{DAFTAR PUSTAKA}

Allen, G. 1999. Marine Fishes of South-East Asia; A guide for anglers and divers. Periplus Editions. Singapore. $292 \mathrm{pp}$.

Ambo-Rappe, R., M.N.Nessa., H. Latuconsina \& D.L. Lajus. 2013. Relationship between the tropical seagrass bed characteristics and the structure of the associated fish community. Open Journal of ecology. Vol.3(5):331-342.

Aswandy, I dan M.H. Azkab. 2000. Hubungan Fauna dengan Padang Lamun. Oseana, 25(3):19-24.

Effendi, H. 2003. Telaah Kualitas Air; Bagi Pengelolaan Sumberdaya dan Lingkungan Perairan. Kanisius. Yogyakarta.

Fujaya, Y. 2004. Fisiologi Ikan: Dasar pengembangan teknik perikanan. Rineka Cipta Jakarta.

Gillanders, B.M. 2006. Seagrasses, Fish and Fisheries. In Larkum. A.W.D., R.J.Orth \& C.M Duarte (ed.) Seagrasses: Biology, Ecology and Conservation. Published By Springer.Netherlands.

Hutomo, M. 1985. Telaah Ekologik Komunitas Ikan padang lamun (Seagrass Antophyta) di perairan Teluk Banten. Disertasi Fakultas Pasca Sarjana IPB. Bogor. 299 pp.

Kordi, M.G.H dan A. Tancung. 2007. Pengelolaan Kualitas Air Dalam Budidaya Perairan. Rineka Cipta. Jakarta. 208 pp.

Kuiter, R.H dan T, Tonozuka. 2001 a. Indonesian Reef Fishes. Part 1. Eels to Snappers: Murainidae to Lutjanidae. Zoonetic,Melbourne. Australia. 153 pp.

Kuiter, R.H dan T, Tonozuka. 2001b. Indonesian Reef Fishes. Part 2. Fusiliers to Dragonets. : Caesionidae to Callyonimidae. Zoonetic,Melbourne. Australia. 161. 
Kuiter, R.H dan T, Tonozuka. 2001c. Indonesian Reef Fishes. Part 3. Jawfishes-Sunfishes. Zoonetic,Melbourne. Australia. 123 pp.

Latuconsina, H., M.N. Nessa, dan R, Ambo-Rappe. 2012. Komposisi Spesies dan Struktur Komunitas Ikan padang Lamun Perairan Tanjung Tiram-Teluk Ambon Dalam. Jurnal Ilmu dan Teknologi Kelautan Tropis. Vol. 4, No. 1, Hal. 35-46.

Latuconsina H, Ambo-Rappe R, Nessa MN. 2013. Asosiasi ikan baronang (Siganus canaliculatus Park, 1797) pada ekosistem padang lamun perairan Teluk Ambon Dalam. In: Simanjuntak CPH (eds.). Prosiding Seminar Nasional Ikan VII. Masyarakat Iktiologi Indonesia. pp. 123-137.

Latuconsina, H dan Ambo-Rappe, R. 2013. Variabilitas Harian Komunitas Ikan Padang Lamun Perairan Tanjung Tiram-Teluk Ambon Dalam. Jurnal Iktiologi Indonesia:13(1): 35-53.

Nagelkerken I, van der Velde G, Gorissen GW, Meijer GJ, van't Hof T, den Hartog C. 2000. Importance of mangroves, seagrass beds and the shallow coral reef as nursery for importance reef fi shes, using a visual cencus technique. Estuarine, Coastal and Shelf Science, 51:31-44.

Pereira PHC, Ferreira BP, Rezende SM. 2010. Community structure of the ichthyofauna associated with seagrass beds (Halodule wrightii) in Formoso River estuary - Pernambuco, Brazil. Anais da Academia Brasileira de Ciências, 82(3): 617-628.

Niarita, C.E., P.Wibowo dan D.Padmawinata (eds). 1996. Ekosistem Lahan Basah Indonesia. Kerja sama antara Wetland International - Indonesia program, Ditjen PHPA, Canada Fund, Pusat Pengembangan Penataran Guru IPA dan British Petrolium. Jakarta.

Soegianto, A. 1995. Ekologi Kuantitatif; Metode Analisis Populasi dan Komunitas. Usaha Nasional. Surabaya.

Setyobudiandi, I., Sulistiono., F. Yulianda., C.Kusmana,C.,S.Hariyadi.,A.Damar., A.Sembiring dan Bahtiar. 2009. Sampling dan Analisis Data Perikanan dan Kelautan; Terapan Metode Pengambilan Contoh di Wilayah Pesisir dan Laut. Fakultas Perikanan dan Ilmu Kelautan.IPB.Bogor. 312 pp.

Supriadi., Y.A.La Nafie dan A.I. Burhanuddin. 2004. Inventarisasi Jenis, Kelimpahan dan Biomas Ikan di Padang Lamun Pulau Barranglompo Makassar. Torani, Vol.14 (5):288-295. Jurnal Ilmu Kelautan dan Perikanan, Universitas Hasanuddin. Makassar.

Odum, E.P. 1983. Basic Ecology. Saunders College Publishing, New York. 612 pp. 